ISSN 0258-7122

Bangladesh J. Agril. Res. 36(4): 623-632, December 2011

\title{
YIELD GAP AND PRODUCTION CONSTRAINTS IN RICE-WHEAT SYSTEM: SCENARIO FROM EASTERN UTTAR PRADESH
}

\author{
MAHENDRA SINGH ${ }^{1}$
}

\begin{abstract}
The yield gap and the production constraints in the rice-wheat (R-W) system in eastern Uttar Pradesh were studied. The yield gap II (difference between the yield obtained at nearest demonstration plot and actual yield obtained on farmers' fields in a particular region) has been found 45 percent and 38 percent in rice and wheat crops, respectively, in the irrigated rice-wheat system. The technological and socio-economic constraints have accounted for 54 percent and 46 percent of the yield gap, respectively, in the system. Soil-related constraints rank first, followed by weed-related constraints. Among the individual constraints, zinc deficiency rank first followed by nitrogen deficiency and incidence of Phalaris minor. The study has concluded that for the sustainability of the R-W system, priority should be accorded to bridge the existing yield gap through addressing the production constraints.
\end{abstract}

Keywords: Production constraints, rice-wheat system, yield gap, socio-economic constraints

\section{Introduction}

Rice and wheat are two main pillars for the food security in India. These two crops, together account for over $58 \%$ of the area and over $77 \%$ of the production of food grains in the country (GoI, 2010). The combined share of these two commodities reported over $90 \%$ of total quantity consumption of cereals in rural India (CSO, 2010). However, compound growth in the area, production, and yield of these two crops has decelerated in recent past. The growth of wheat area, production, and yield during 1980 s was $0.46 \%, 3.57 \%$, and $3.10 \%$ per annum, which changed to $1.72 \%, 3.57 \%$, and $1.83 \%$ in 1990 s and decelerated to $1.21 \%$, $1.89 \%$, and $0.68 \%$ during the period of first decade of the twenty first century. In rice, the growth rate of area, production, and yield were $0.41 \%, 3.62 \%$, and $3.19 \%$ per annum, which decelerated to $0.68 \%, 2.02 \%$, and $1.34 \%$ and further decelerated to $-0.03 \%, 1.59 \%$, and $1.61 \%$ during corresponding period (GoI, 2010). These scenarios prove that there is no further scope for area expansion and productivity growth in these two crops. It is also documented that yield stagnation and other problems such as depletion in groundwater table, deterioration of soil health for production of rice and wheat occurred in the state of Punjab, Haryana, and Western part of Uttar Pradesh where Green Revolution technologies adopted in early than in eastern India. Hence, to increase the

${ }^{1}$ Division of Agricultural Economics, Indian Agricultural Research Institute (IARI), New Delhi-110012. 
production, judicious option is only to bridge the yield gap in eastern India where there are abundant availability of groundwater with suitable agro-climatic condition and huge yield potential in these two crops.

The rice-wheat system is being practised in Uttar Pradesh (UP) since 1872 $\mathrm{AD}$ and the area under rice-wheat (R-W) sequence in India was estimated to be nearly 11 million hectares during 1996-98. Nearly half of this area is in UP and within the state, the system is largely concentrated in the eastern region to the extent that about $22 \%$ of the total area under R-W system of the area in the country (Singh, 2001). This region is characterized by inadequate irrigation, low levels of input-use, traditional practices, frequent flooding and other weatherinduced risks. It also requires a different technological, infrastructural and policy support from the northern region. While some studies have analysed the performance of R-W system in the northern India (IRRI, 1990; Hobbs et al., 1992, Chaudhary and Harrington, 1993; Harrigton et al., 1993; Roy and Dutta, 2000), systematic studies focusing on the eastern Uttar Pradesh are relatively few. Therefore, the present study has examined the yield gap and production constraints of R-W system in the eastern UP.

\section{Methodology}

\section{Study area and sources of data}

Eastern Uttar Pradesh comprises twenty eight districts, which classified into three agroecological zones, namely Eastern Plain Zone, North-Eastern Plain Zone, and Vindhya Zone, and occupies one-third of the net sown area of Uttar Pradesh.

Secondary data collected from 'Uttar Pradesh Ke Krishi Akre' annual publication of Department of Agriculture, Government of Uttar Pradesh and used for categorization of the districts on the basis of yield of rice and wheat. For identification of production constraints, primary as well as secondary data were used. The production constraints were elicited from the scientists, extension personnel, and other government officials. These data were collected from farmers practising the $\mathrm{R}-\mathrm{W}$ system. For the selection of sample farmers, 15 districts (Azamgarh, Mau, Bahraich, Shrawasti, Basti, Sidharth Nagar, Sant Kabir Nagar, Deoria, Kushi Nagar, Faizabad, Ambedkar Nagar, Gorakhpur, Maharajganj, Gonda and Balrampur) were selected with higher proportion of RW system. From each district, two blocks and from each block, one village was selected randomly. All the farmers in a village were grouped into three categories on the basis of their size of holdings. A total of 10 farmers from each village were selected. Thus, a total of 140 farmers were selected for the detailed farm survey. 


\section{Estimation of yield gap}

In this study, the concept of yield gap as suggested by Zandstra et al. (1981) was used. This total yield gap can be decomposed into two parts, viz. Yield gap I and Yield gap II. Yield Gap I refers to the difference between research station yield and potential farm yield obtained at demonstration plots, while Yield Gap II, reflecting the effects of biophysical and socio-economic constraints, is the difference between yield obtained at the nearest demonstration plot and actual yield obtained on farmers' fields. This gap was of prime concern in the present study. The yield gaps were estimated as follows:

Yield Gap I= $\left[\left(\mathrm{Y}_{\mathrm{R}}-\mathrm{Y}_{\mathrm{D}}\right) / \mathrm{Y}_{\mathrm{R}}\right] \times 100$

Yield Gap II $=\left[\left(\mathrm{Y}_{\mathrm{D}}-\mathrm{Y}_{\mathrm{F}}\right) / \mathrm{Y}_{\mathrm{D}}\right] \times 100$

Where. $Y_{R}$ is the research station yield, $Y_{D}$ is the demonstration plot yield, and $\mathrm{Y}_{\mathrm{F}}$ is the actual farm yield.

\section{Estimation of production losses due to various constraints}

The severity of technological constraints was assessed through estimation of production losses. The proportion of area affected, average yield loss and frequency of occurrence being indicators of severity of a constraint, information on these aspects was collected from the sample farmers based on their experience and perceptions. The estimates were averaged for rice and wheat separately for each constraint. The production losses were calculated on the basis of area affected and yield loss per hectare due to a particular constraint in the region. The production losses were multiplied by the procurement price to get the value of production foregone a constraint. All technological constraints were ranked on the basis of the value of production loss. The socio-economic constraints were ranked on the basis of percentage of sample farmers reporting about a particular constraint.

\section{Results and Discussion}

\section{Categorization of the districts on the basis of productivity of rice and wheat in Eastern Uttar Pradesh}

The categorization of the districts in eastern Uttar Pradesh on the basis of yield of rice is presented in Table 1. It shows that none of the district occupies the position in the category of High productivity districts (2.5-3.5 t/ha) and all the districts except Ballia and Sonbhadra were concentrated in categories of medium to medium-low productivity districts (1.5 to $2.5 \mathrm{t} / \mathrm{ha}$ ). 
Table 1. Categorization of the districts on the basis of productivity of rice in eastern Uttar Pradesh, 2007-09.

\begin{tabular}{l|l}
\hline Category & District \\
\hline High productivity districts & None
\end{tabular}
(2.5-3.5 t/ha)

Medium productivity districts (2.0-2.5 t/ha)

Medium-low productivity districts (1.5-2.0 t/ha)

Low productivity districts (1.0-1.5 t/ha)

Very low productivity districts None $(<1.0 \mathrm{t} / \mathrm{ha})$

Source: Author's calculation with data from Directorate of Agriculture, Government of Uttar Pradesh, Lucknow.

The categorization of the districts on the basis of yield of wheat is presented in Table 2. It shows that all the districts except Sonbhadra are concentrated into categories of high and medium productivity (2.0-3.5 t/ha).

Table 2. Categorization of the districts on the basis of productivity of wheat in eastern Uttar Pradesh, 2007-09.

\begin{tabular}{l|l}
\hline Category & District \\
\hline $\begin{array}{l}\text { High productivity districts ( 2.5- } \\
3.5 \text { t/ha) }\end{array}$ & $\begin{array}{l}\text { Balrampur, Ambedkar Nagar, Kushinagar, } \\
\text { Maharajganj, Barabanki, Sultanpur, Gonda, }\end{array}$ \\
& $\begin{array}{l}\text { Faizabad, Deoria, Gorakhpur, Bahraich, Jaunpur, } \\
\text { Sant Kabir Nagar, Ballia, Azamgarh, Mau, Varanasi }\end{array}$ \\
$\begin{array}{l}\text { Medium productivity districts } \\
(2.0-2.5 \text { t/ha) }\end{array}$ & $\begin{array}{l}\text { Ghazipur, Basti, Pratapgarh, Shrawasti, Chandauli, } \\
\text { Sidharthnagar, Allahabad, Sant Rabidas Nagar, }\end{array}$ \\
$\begin{array}{l}\text { Medium-low productivity } \\
\text { districts (1.5-2.0 t/ha) }\end{array}$ & $\begin{array}{l}\text { Kaushambhi, Mirzapur } \\
\text { Low productivity districts (1.0- } \\
1.5 t / \text { ha) }\end{array}$ \\
$\begin{array}{l}\text { Very low productivity districts } \\
(<1.0 \text { t/ha) }\end{array}$ & None \\
\hline
\end{tabular}

Source: Author's calculation with data from Directorate of Agriculture, Government of Uttar Pradesh, Lucknow. 


\section{Estimation of yield gap in rice and wheat}

As seen from Table 3, the estimated yield gap I was $0.174 \mathrm{t} / \mathrm{ha}(5 \%)$ and yield gap II was $1.45 \mathrm{t} /$ ha (42 \%) in the case of rainfed rice. In irrigated rice, yield gap I was $0.631 \mathrm{t} / \mathrm{ha}(12 \%)$, while yield gap II was $2.030 \mathrm{t} / \mathrm{ha}(45 \%)$. In the wheat crop, yield gap I was $1.636 \mathrm{t} / \mathrm{ha}$ (29\%) and yield gap II was $1.519 \mathrm{t} / \mathrm{ha}$ (38 \%). It implies that average yield of rice and wheat was much below the potential yield in the region. The yield gap II was $2 \mathrm{t} / \mathrm{ha}$ and $1.5 \mathrm{t} / \mathrm{ha}$ in rice and wheat respectively, and much scope for yield enhancement in these two crops in the region.

Table 3. Yield gaps in rice-wheat system at Faizabad centre in eastern Uttar Pradesh (t/ha).

\begin{tabular}{l|lll|l}
\hline \multirow{2}{*}{ Particular } & \multicolumn{2}{c|}{ Rice } & \multicolumn{1}{c}{ Wheat } \\
\cline { 2 - 4 } & \multicolumn{2}{|c}{ Rainfed } & \multicolumn{1}{c}{ Irrigated } & \multicolumn{1}{c}{ Irrigated } \\
\hline Average research station yield & 3.629 & 5.141 & 5.675 \\
Average front line demonstration yield & 3.455 & 4.510 & 4.039 \\
Average actual farm yield & 2.000 & 2.480 & 2.520 \\
Yield gap I & 0.174 & 0.631 & 1.636 \\
& $(5)$ & $(12)$ & $(29)$ \\
Yield gap II & 1.455 & 2.030 & 1.519 \\
& $(42)$ & $(45)$ & $(38)$ \\
Total yield gap & 1.629 & 2.661 & 3.155 \\
& $(47)$ & $(57)$ & $(67)$ \\
\hline
\end{tabular}

Source: Experimental and demonstration yield data from coordinated projects and frontline demonstrations.

\section{Estimation of value of yield losses in rice - wheat system in eastern Uttar Pradesh}

Considering rice and wheat together for the irrigated rice-wheat system, the shares of technological and socio economic constraints were found as 54 percent and 46 percent, respectively (Table 4). Within the technological constraints, soil related constraints ranks first followed by weeds, diseases, insect pests and climate related constraints in irrigated rice-wheat system in eastern Uttar Pradesh. 
Table 4. Estimates of yield losses due to major constraints in irrigated ricewheat system in eastern Uttar Pradesh.

\begin{tabular}{|c|c|c|c|}
\hline Constraints & $\begin{array}{c}\text { Average } \\
\text { estimated yield } \\
\text { loss }(\mathrm{kg} / \mathrm{ha})\end{array}$ & Yield gap II (\%) & $\begin{array}{l}\text { Estimated value } \\
\text { of yield lossess } \\
\text { (in crore Rs.) }\end{array}$ \\
\hline \multicolumn{4}{|l|}{ Technological constraints } \\
\hline \multicolumn{4}{|l|}{ Abiotic constraints } \\
\hline Climate related constraints & 136 & 7.1 & 164 \\
\hline Soil related constraints & 892 & 46.4 & 1077 \\
\hline \multicolumn{4}{|l|}{ Biotic constraints } \\
\hline Insect pests & 164 & 8.5 & 196 \\
\hline Diseases & 219 & 11.4 & 263 \\
\hline Nematodes & 29 & 1.5 & 35 \\
\hline Weeds & 460 & 23.9 & 558 \\
\hline Rodents & 7 & 0.4 & 85 \\
\hline Wild cow & 9 & 0.5 & 13 \\
\hline Technological constraints & 1916 & 54 & 2391 \\
\hline Socio-economic constraints & 1633 & 46 & 1899 \\
\hline Total & 3549 & 100 & 4290 \\
\hline
\end{tabular}

Source: Author's calculations with data from selected farmers' and extension personal in the region.

\section{Prioritization of the production constraints in irrigated rice-wheat system}

The technological constraints were prioritized on the basis of the value of yield losses in irrigated rice-wheat system (Table 5). Among the individual constraints, zinc deficiency, nitrogen deficiency, and stem borer occupied top ranked in rice crop, while Phalaris minor, nitrogen deficiency, and phosphorus deficiency were important in wheat. It implies that to minimize the yield gap, these important constraints should be given priority in that order in the region.

The socio-economic constraints were ranked on the basis of opinions and perceptions of the respondents (Table 6). Among the socio-economic constraints, lack of knowledge about new technologies ranked first followed by lower share of nutrient supply through FYM and poor extension facilities. 
Tables 5. Priority ranking based on value of production losses in irrigated rice-wheat system in eastern Uttar Pradesh.

\begin{tabular}{|c|c|c|c|}
\hline Priority ranks & Rice & Wheat & Rice-wheat system \\
\hline 1 & Zinc deficiency & Phalaris minor & Zinc deficiency \\
\hline 2 & Nitrogen deficiency & Nitrogen deficiency & Nitrogen deficiency \\
\hline 3 & Stem borer & Phosphorus deficiency & Phalaris minor \\
\hline 4 & Phosphorus deficiency & Avena spp. & Phosphorus deficiency \\
\hline 5 & Drought & Chenopodium album & Stem borer \\
\hline 6 & Cynodon dactilon & $\begin{array}{l}\text { Late season moisture } \\
\text { stress }\end{array}$ & Avena spp. \\
\hline 7 & False smut & Hailstorm & $\begin{array}{l}\text { Late season moisture } \\
\text { stress }\end{array}$ \\
\hline 8 & Waterlogging & Melilotus albs & Potash deficiency \\
\hline 9 & Sulphur deficiency & Zinc deficiency & Chenopodium, album \\
\hline 10 & Sheath rot & Potash deficiency & Cynodon dactilon \\
\hline 11 & Brown spot & $\begin{array}{l}\text { Anguina tritici } \\
\text { (nematodes) }\end{array}$ & Drought \\
\hline 12 & Flood & Fumeria parvi & Sulphur deficiency \\
\hline 13 & Cyprus rotendus & Foliar blight & Hailstorm \\
\hline 14 & $\begin{array}{l}\text { White-backed } \\
\text { planthopper }\end{array}$ & Cynodon dactilon & False smut \\
\hline 15 & Potash deficiency & Loose smut & Stem borer \\
\hline 16 & $\begin{array}{l}\text { Late season moisture } \\
\text { stress }\end{array}$ & Wild cow & Chenopodium album \\
\hline 17 & Sheath blight & Karnal bunt & Waterlogging \\
\hline 18 & Selaria glauca & Sulphur deficiency & Sheath rot \\
\hline 19 & Leaf folder & Rodents & Melilotus alba \\
\hline
\end{tabular}

Source: Author's calculations with data from selected farmers' and extension personnal in the region. 
Table 6. Ranking of identified socio-economic constraints for the irrigated rice-wheat system in eastern Uttar Pradesh.

\begin{tabular}{|c|c|c|}
\hline Constraints & $\begin{array}{l}\text { Frequency of } \\
\text { constraints } \\
\text { reported by } \\
\text { farmers }\end{array}$ & Rank \\
\hline $\begin{array}{l}\text { Lack of knowledge about Integrated Plant Nutrients } \\
\text { Management (IPNM), Integrated Pest Management (IPM), low } \\
\text { input cost technologies such as blue green algae, new varieties } \\
\text { and improved technologies suitable for stress environment, zero } \\
\text { tillage and crop residue management }\end{array}$ & 29 & 1 \\
\hline $\begin{array}{l}\text { Low share of nutrients supply through FYM in total nutrient } \\
\text { supply, lion's share of animal dung used as fuel }\end{array}$ & 23 & 2 \\
\hline Poor reach to extension agencies and lack of demonstration trials & 17 & 3 \\
\hline Low irrigation facilities and erratic supply of electricity & 15 & 4 \\
\hline $\begin{array}{l}\text { Low pulses area related to rice-wheat system area and lack of } \\
\text { suitable cropping sequence }\end{array}$ & 14 & 5 \\
\hline Lack of output market infrastructure & 11 & 6 \\
\hline Lack of proper developed road infrastructure & 10 & 7 \\
\hline $\begin{array}{l}\text { Small and fragmental holding and limited resource base of } \\
\text { farmers }\end{array}$ & 8 & 8 \\
\hline $\begin{array}{l}\text { Lack of improved implements and supply of quality agro- } \\
\text { chemicals and seed }\end{array}$ & 7 & 9 \\
\hline Declining area under common property land & 6 & 10 \\
\hline
\end{tabular}

Source: Author's calculations with data from selected farmers' and extension personnel in the region.

Based on the study, the policy implications for sustainability of the rice-wheat production system are presented in Table7. 
Table 7. Policy implications for sustainability of rice-wheat system in eastern Uttar Pradesh.

\begin{tabular}{|c|c|c|c|c|}
\hline \multirow{2}{*}{ Constraints } & \multirow{2}{*}{ Possible causes } & \multirow{2}{*}{ Opportunity } & \multicolumn{2}{|c|}{ Suggestions } \\
\hline & & & Research theme & Policy tools \\
\hline $\begin{array}{l}\text { Soil-related } \\
\text { constraints }\end{array}$ & $\begin{array}{l}\text { Un-scientific crop } \\
\text { rotation, imbalanced use } \\
\text { of fertilizers and steady } \\
\text { decline in use of organic } \\
\text { manure }\end{array}$ & $\begin{array}{l}\text { Adoption of } \\
\text { integrated plant } \\
\text { nutrient } \\
\text { management and } \\
\text { resource } \\
\text { conservation } \\
\text { technologies, } \\
\text { such as zero } \\
\text { tillage }\end{array}$ & $\begin{array}{l}\text { Diagnosis of } \\
\text { constraints for } \\
\text { adoption of } \\
\text { integrated plant } \\
\text { nutrient } \\
\text { management } \\
\text { and resource } \\
\text { conservation } \\
\text { technologies } \\
\text { and suitable } \\
\text { alternatives for } \\
\text { FYM }\end{array}$ & $\begin{array}{l}\text { Suitable policy for } \\
\text { encouragement of } \\
\text { balanced use of } \\
\text { fertilizers, bio- } \\
\text { fertilizers, FYM and } \\
\text { other organic } \\
\text { manures }\end{array}$ \\
\hline $\begin{array}{l}\text { Weed-related } \\
\text { constraints }\end{array}$ & $\begin{array}{l}\text { Continuous R-W crop } \\
\text { rotation, spurious supply } \\
\text { of weedicides besides } \\
\text { decline in efficacy of } \\
\text { existing weedicides }\end{array}$ & $\begin{array}{l}\text { Suitable crop } \\
\text { rotation, supply } \\
\text { of quality } \\
\text { weedicides and } \\
\text { promotion of } \\
\text { integrated weed } \\
\text { management }\end{array}$ & $\begin{array}{l}\text { Development of } \\
\text { efficient } \\
\text { weedicides, } \\
\text { crop specific } \\
\text { module for } \\
\text { weed } \\
\text { management }\end{array}$ & $\begin{array}{l}\text { Suitable policy to } \\
\text { check supply of } \\
\text { quality weedicides } \\
\text { and encouragement } \\
\text { of integrated weed } \\
\text { management }\end{array}$ \\
\hline $\begin{array}{l}\text { Slow } \\
\text { adoption of } \\
\text { new } \\
\text { technology } \\
\text { and poor } \\
\text { extension } \\
\text { support } \\
\text { system }\end{array}$ & $\begin{array}{l}\text { Lack of up-to-date } \\
\text { knowledge of new } \\
\text { technologies besides } \\
\text { steady decline of } \\
\text { government support }\end{array}$ & $\begin{array}{l}\text { Suitable policy } \\
\text { for technologies } \\
\text { transfer from } \\
\text { research station } \\
\text { to farmers field }\end{array}$ & $\begin{array}{l}\text { Development of } \\
\text { location } \\
\text { specific } \\
\text { technologies } \\
\text { and its } \\
\text { refinement } \\
\text { through } \\
\text { farmers' } \\
\text { participation }\end{array}$ & $\begin{array}{l}\text { Suitable policy for } \\
\text { strengthening of } \\
\text { linkages among } \\
\text { state agricultural } \\
\text { universities, } \\
\text { development } \\
\text { departments, Krishi } \\
\text { Vigyan Kendras and } \\
\text { farmers }\end{array}$ \\
\hline
\end{tabular}

\section{Conclusions and policy implications}

The study has shown that there is a huge potential to increase crop yields at farm level. The main socio-economic constraint reported to lack of knowledge about improved technologies, which could be addressed by strengthening extension services. Suitable policy for gradually encouragement for use of balanced fertilizers along with FYM, supply of quality inputs apart from strengthening of linkage between research institutes and farmers are imperative for sustainability of the system. Concerted efforts are needed to bridge the yield gap through translation of prioritised production constraints into research objectives and allocating resources to research and development. At the same time, development of infrastructure and rural institutions are essential to further accelerate and sustain the productivity growth in the region. 


\section{Acknowledgements}

The author is grateful to Dr Suresh Pal, Head and Dr V.C. Mathur, Professor, Division of Agricultural Economics for their suggestions on this paper. He is also thankful to the anonymous referee for his critical comments on this paper.

\section{References}

Chaudhary, M. K. and L. W. Harrington. 1993 Rice- Wheat System in Haryana inputOutput trends and sources of future productivity Growth. CCS Haryana Agriculture University, Hissar, CIMMYT, Working Paper, Mexico, 61 p.

Government of India. 2010. Agricultural Statistics at a Glance, Directorate of Economics and Statistics, Department of Agriculture and Cooperation, Ministry of Agriculture, New Delhi.

Harrington, L.W., M. L. Fujusaka, P. R. Morris, H. C. Hobbs, R. P. Sharma, M. K. Singh, Chaudhary and S. D. Dhiman. 1993. Wheat and Rice in Karnal and Kurukshetra Districts, Haryana, India; farmers' Practices, Problems and and Agenda for Action. HAU, ICAR, CIMMYT and IRRI. $44 \mathrm{p}$.

Hobbs, P. R., G.P. Hettel, R.K. Singh, R.P. Singh, L.W. Harrington, V.P. Singh and K.G. Pillai. 1992. Rice- Wheat Cropping System in Faizabad District in Uttar Pradesh, India:

Exploratory Surveys of Farmers' Practices and Problems and Needs for Further Research, ICAR, NDAUT, CIMMYT and IRRI. $61 \mathrm{p}$.

IRRI. 1990. Diagnostic surveys of the Rice-Wheat system in the Terai of India, pp.53-55 in Programme Report for 1990, Manila, Philippines.

Islam, Md. Nozrul, J. K. Saha and S.M. Elias. 1992. Constraints to farm level wheat cultivation in Bangladesh. Bangladesh Journal of Agricultural Research. 17(1):83-88 pp.

Roy, B.C. and K.K. Dutta. 2000. Rice-Wheat system in Haryana: Prioriting production constraints and implcation for future Research. Indian Journal of Agricultural Economics 55(4):671-682 pp.

GoUP. Uttar Pradesh Ke Krishi Ankre (various issues), Directorate of Agriculture, Government of Uttar Pradesh, Lucknow.

Woodhead, T., R. Huke, E. Huke and L. Balababa. 1994. Rice-wheat Atlas of India. IRRI, CIMMYT and ICAR. $147 \mathrm{p}$.

Zandstra, H.G., E.C., Price, J.A., Litsinger and R.A. Morris. 1981. A methodology for on-farm cropping systems research, IRRI, Manila, Philippines, $147 \mathrm{p}$.

Singh M. 2001. Sustainability of rice-wheat system in eastern Uttar Pradesh: An economic perspective. Ph. D. dissertation, Indian Agricultural Research Institute, New Delhi. 